\title{
SNW1 wt Allele
}

National Cancer Institute

\section{Source}

National Cancer Institute. SNW1 wt Allele. NCI Thesaurus. Code C52158.

Human SNW1 wild-type allele is located in the within 14q22.1-q22.3 and is approximately $43 \mathrm{~kb}$ in length. This allele, which encodes SNW domain containing protein 1, is involved in nuclear receptor-mediated activation of transcription. 